\title{
AKRUAL
}

Jurnal Akuntansi

http://fe.unesa.ac.id/ojs/index.php/akrl

\section{PERSEPSI APARATUR DAN PENERIMAAN PBB-P2 SEBELUM SESUDAH PENERAPAN PBB-P2 SEBAGAI PAJAK DAERAH (STUDI KASUS DI KABUPATEN SIDOARJO)}

\author{
Alim Nur Siswanti \\ Junaidi \\ Gita Arasy Harwida \\ FEB Universitas Trunojoyo Madura \\ Email: alimsiswanti@gmail.com \\ Artikel diterima : 23 Mei 2013 \\ Revisi terakhir : 3 September 2013
}

\begin{abstract}
The objective of this study was to discover of all DPPKA and UPTD officers and to examine the difference of $P B B-P 2$ revenue as local tax with descriptive quantitative methodology. The population was 43 consisted of all DPPKA's billing and services department, all UPTD in Sidoarjo, and all revenue PBB-P2 from 18 districts from the year of 2011 and 2012. The method of collecting data was giving questionnaire, interview, and from secondary data. The result of this study shows the difference of the $P P B-P 2$ revenue between before and after the enactment of $P B B-P 2$ as the local tax. This is proven that by the good perception that indicated by the officers, it is also indicated the increasing of revenue from PBB-P2, thus, the PAD of kabupaten Sidoarjo will also be increased.
\end{abstract}

Keywords: PBB-P2, The Perception of Officer, Revenue of PBB-P2

\section{PENDAHULUAN}

Pemberlakukan efektif otonomi daerah pada tahun 2000, membuat pemerintah mengeluarkan UU Nomor 34 Tahun 2000 tentang Perubahan Kedua atas UU Nomor 18 Tahun 1997 tentang Pajak Daerah dan Retribusi Daerah. Seiring dengan semakin banyaknya potensi pajak daerah yang dapat digali pada setiap daerah, tahun 2009 Pemerintah Pusat memunculkan wacana untuk mengalihkan dua jenis pajak pusat sebagai pajak daerah. Kedua pajak tersebut adalah Bea Perolehan Hak atas Tanah dan Bangunan (BPHTB) dan Pajak Bumi dan Bangunan sektor Perdesaan dan Perkotaan (PBB-P2).

Menurut Simanjuntak (2003) dalam Tasniwati (2010) menyebutkan bahwa dilihat dari berbagai segi, PBB dan BPHTB lebih merupakan pajak daerah dari pada pajak pusat. Hal ini dikarenakan objek pajak dari PBB itu sendiri berada di daerah yang pengurusan segala bentuk administrasinya juga di daerah. Penyerahan PBB sebelum diserahkan daerah, pihak Pemerintah Pusat terlebih dahulu memotong upah pungut PBB baru kemudian diserahkan kembali kepada daerah. Hal tersebut akan membuat dua kali pekerjaan karena setelah diserahkan ke daerah untuk memungut pajak, kemudian daerah akan kembali menyetorkan PBB kepada Pemerintah Pusat. Barulah daerah akan menunggu dana bagi hasil 
atas PBB yang telah disetorkan berdasarkan prosentase banyaknya penerimaan PBB dan bagi hasil rata dengan seluruh daerah. Hal tersebut senada dengan penelitian Sari (2010) yang mengatakan dari segi substansi pajak, kewenangan pemajakan atas tanah dan bangunan merupakan hak dari Pemerintah Daerah dengan kata lain, hak pemajakan PBB-P2 sejatinya berada pada Pemerintah Daerah bukan pada Pemerintah Pusat.

Pemerintah Pusat tidak berpangku-tangan untuk proses pengalihan ini. Banyak hal yang telah dipersiapkan oleh Pemerintah Pusat untuk proses pengalihan PBB-P2 sebagai pajak daerah. Hal-hal yang dipersiapkan UU Nomor 28 Tahun 2009 tentang Perubahan Ketiga atas UU Nomor 34 Tahun 2000 tentang Pajak Daerah dan Retribusi Daerah adalah Peraturan Bersama Menteri Keuangan dan Menteri Dalam Negeri Nomor 213/PMK.07/2010 Nomor 58 Tahun 2010 Tentang Tahapan Persiapan Pengalihan Pajak Bumi dan Bangunan Perdesaan dan Perkotaan Sebagai Pajak Daerah. PMK Nomor 213/PMK.07/2010 Nomor 58 Tahun 2010 tersebut adalah pedoman utama yang harus digunakan oleh Pemerintah.

Alasan penulis memilih Kabupaten Sidoarjo sebagai objek penelitian karena berdasarkan data Badan Pusat Statistik Jawa Timur tahun 2011, Kabupaten Sidoarjo merupakan kabupaten dengan penerimaan pajak daerah terbesar se-Jawa Timur dengan realisasi sebesar Rp. 265.425.000.000,00 dari target yang ditentukan Rp. 223.500.000.000,00. Sedangkan berdasarkan data dari Dinas Pendapatan Pengelolaan dan Keuangan Aset (DPPKA) Kabupaten Sidoarjo tahun 2012, penerimaan PBB-P2 ditargetkan sebesar Rp. 103.518.000.000,00 dengan realisasi sampai dengan bulan April 2012 sebesar Rp. 11.624.147.774,00.

Hal ini senada dengan penelitian sebelumnya yang dilakukan oleh Sari (2010) yang mengatakan bahwa setelah menjadi pajak daerah maka seluruh penerimaan PBB Perdesaan dan Perkotaan akan menjadi bagian dari Pendapatan Asli Daerah (PAD). Selain itu Bagijo (2011) juga menyatakan bahwa posisi PDRD sangat strategis bagi penyelenggaraan Pemerintah Daerah khususnya sebagai indikator keberhasilan otonomi daerah untuk membiayai seluruh pelaksanaan urusan wajib daerah. Dengan demikian, penerimaan pajak daerah yang tinggi akan mempengaruhi naiknya Pendapatan Asli Daerah (PAD) Kabupaten Sidoarjo seiring banyaknya pajak yang dikelola oleh Pemerintah Daerah.

Berdasarkan uraian di atas, rumusan masalah yang diajukan "Bagaimana persepsi aparat Pemda Kabupaten Sidoarjo terhadap pelaksanakan PBB-P2 sebagai pajak daerah sesuai dengan Perda Kabupaten Sidoarjo Nomor 11 Tahun 2011 menurut PMK Nomor 213/PMK.07/2010 Nomor 58 Tahun 2010 dengan indikator sarana dan prasarana; struktur organisasi dan tata kerja; sumber daya manusia; Perda, Perkada dan SOP; kerjasama dengan pihak terkait dan pembukaan rekening penerimaan PBB-P2 pada bank yang sehat?" dan "Apakah terdapat perbedaan penerimaan PBB-P2 sebelum dan sesudah penerapan PBB-P2 sebagai pajak daerah di Kabupaten Sidoarjo?". Tujuan penelitian ini untuk mengetahui persepsi Aparat Pemda Kabupaten Sidoarjo terhadap penerapan PBBP2 sebagai pajak daerah setelah berlakunya Perda Kabupaten Sidoarjo Nomor 11/2011 menurut PMK Nomor 213/PMK.07/2010 Nomor 58 Tahun 2010 dan 
untuk menguji perbedaan penerimaan PBB-P2 sebelum dan sesudah penerapan PBB-P2 sebagai pajak daerah. Penelitian ini dihrapkan mampu memberikan wawasan dan pengetahuan tentang pemahaman PBB-P2 sebagai pajak daerah.

\section{KAJIAN PUSTAKA \\ Objek PBB Perdesaan dan Perkotaan}

Berdasarkan amanat Undang-Undang Nomor 28 Tahun 2009 tentang Perubahan Ketiga atas UU Nomor 34 Tahun 2000 tentang PDRD pasal 77 ayat (1) Perda Kabupaten Sidoarjo Nomor 11 Tahun 2011 pasal 3 ayat (2), objek PBB-P2 adalah Bumi dan/atau Bangunan yang dimiliki, dikuasai, dan/atau dimanfaatkan oleh orang pribadi atau Badan, kecuali kawasan yang digunakan untuk kegiatan usaha perkebunan, perhutanan, dan pertambangan.

\section{Perhitungan PBB-P2 Sebagai Pajak Pusat vs Pajak Daerah}

Tabel 1. Perbedaan PBB-P2 sebagai Pajak Pusat vs Pajak Daerah

\begin{tabular}{|c|c|c|c|}
\hline & $\begin{array}{l}\text { PBB-P2 sebagai Pajak } \\
\text { Pusat (UU No. 12/1985) }\end{array}$ & 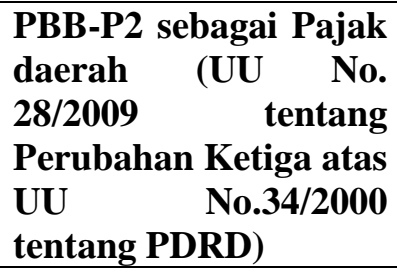 & $\begin{array}{l}\text { PBB-P2 sebagai } \\
\text { Pajak } \\
\text { (Perda } \\
\text { Kabupaten } \\
\text { Sidoarjo Nomor } \\
\text { 11 Tahun 2011) }\end{array}$ \\
\hline Pembagian & $\begin{array}{l}\text { Ketika masih sebagai pajak } \\
\text { pusat penerimaan PBB-P2 } \\
\text { merupakan Dana Bagi Hasil } \\
\text { antara: } \\
\text { a. Pemerintah Pusat }=10 \% \\
\text { b. Pemda/Pemkot }=64,8 \% \\
\text { c. Pemprov }=16,2 \% \\
\text { d. Biaya Pemungutan }=9 \% \\
\text { (PP No.16 Tahun 2000) }\end{array}$ & $\begin{array}{lrr}\text { Setelah sebagai } & \text { pajak } \\
\text { daerah maka PBB-P2 } & \text { maka } \\
100 \% \text { merupakan } \\
\text { penerimaan } r \text { murni } \\
\text { daerah dan } & \text { secara } \\
\text { otomatis masuk } & \text { PAD } \\
\text { bukan lagi Dana } & \text { Bagi } \\
\text { Hasil. } & & \end{array}$ & $\begin{array}{lr}\text { Setelah sebagai } \\
\text { pajak daerah maka } \\
\text { PBB-P2 } 100 \% \\
\text { merupakan } \\
\text { penerimaan } \\
\text { daerah dan secara } \\
\text { otomatis masuk } \\
\text { PAD bukan lagi } \\
\text { Dana Bagi Hasil. }\end{array}$ \\
\hline Tarif & $\begin{array}{l}\text { Sebesar 0,5\% } \\
\text { (Pasal 5) }\end{array}$ & $\begin{array}{l}\text { Paling tinggi } 0,3 \% \\
\text { (Pasal 80) }\end{array}$ & $\begin{array}{l}<1 \mathrm{M} \text { tarif } 0,105 \% \\
>1 \mathrm{M} \text { tarif } 0,225 \% \\
\text { (Pasal } 7)\end{array}$ \\
\hline NJKP & $\begin{array}{l}20 \% \text { s.d. } 100 \% \text { (PP } 25 \\
\text { Tahun } 2002 \text { ditetapkan } \\
\text { sebesar } 20 \% \text { atau } 40 \%) \\
\text { (Pasal 6) }\end{array}$ & Tidak dipergunakan & $\begin{array}{l}\text { Tidak } \\
\text { dipergunakan }\end{array}$ \\
\hline NJOPTKP & $\begin{array}{lll}\text { Setinggi-tingginya } & R p & 12 \\
\text { juta } & & \\
\text { (Pasal 3 Ayat 3) } & & \end{array}$ & $\begin{array}{l}\text { Paling rendah Rp } 10 \\
\text { juta } \\
\text { (Pasal } 77 \text { Ayat 4) }\end{array}$ & $\begin{array}{l}\text { Ditentukan sebesar } \\
\text { Rp } 10 \text { juta } \\
\text { (Pasal } 3 \text { Ayat 5) }\end{array}$ \\
\hline $\begin{array}{l}\text { PBB } \\
\text { Terutang }\end{array}$ & $\begin{array}{llll}\text { Tarif } x \text { NJKP } & \text { x } & \text { (NJOP- } \\
\text { NJOPTKP) } & & \\
0,5 \% \quad x \quad 20 \% & x & \text { (NJOP- } \\
\text { NJOPTKP) } & & \\
0,5 \% \quad x \quad 40 \% & \text { x } & \text { (NJOP- } \\
\text { NJOPTKP) } & & \\
(\text { Pasal 7) } & & \\
\end{array}$ & $\begin{array}{l}\text { Max: 0,3\% x (NJOP- } \\
\text { NJOPTKP) } \\
\text { (Pasal 81) }\end{array}$ & $\begin{array}{l}\text { Tarif } \quad \mathrm{x} \quad(\mathrm{NJOP}- \\
\text { NJOPTKP) } \\
<1 \mathrm{M} \text { tarif } 0,105 \% \\
>1 \mathrm{M} \text { tarif } 0,225 \% \\
(\text { Pasal } 8)\end{array}$ \\
\hline
\end{tabular}

Sumber: Data diolah, 2013 


\section{Tata Cara Pemungutan PBB-P2}

Berdasarkan Peraturan Bupati Sidoarjo Nomor 55 Tahun 2011 pasal 2 ayat (1) menjelaskan tara cara pemungutan PBB mencakup seluruh rangkaian proses yang harus dilakukan dalam menatausahakan, menerima, dan melaporkan penerimaan PBB. Pasal 2 ayat (2) tata cara pemungutan meliputi:

a. Prosedur pendaftaran, pendataan, dan penilaian objek pajak;

b. Prosedur penerbitan, penelitian dan pembetulan SPPT;

c. Prosedur pembayaran PBB;

d. Prosedur pelaporan PBB;

e. Prosedur penagihan PBB;

f. Prosedur pengurangan $\mathrm{PBB}$ dan pengembalian pembayaran $\mathrm{PBB}$.

\section{Instrumen Persiapan Pengalihan PBB Perdesaan dan Perkotaan}

Berdasarkan Peraturan Bersama Menteri Keuangan dan Menteri Dalam Negeri Nomor 213/PMK.07/2010 Nomor 58 Tahun 2010 Tentang Tahapan Persiapan Pengalihan Pajak Bumi dan Bangunan Perdesaan dan Perkotaan Sebagai Pajak daerah pasal (3), terdapat beberapa hal yang harus dikompilasi oleh DJP baru kemudian diserahan kepada pemerintah daerah, yaitu:

1. Peraturan pelaksanaan PBB-P2 sebagai bahan acuan pemerintah daerah dalam menyusun Peraturan Daerah dan Peraturan Kepala Daerah;

2. Standard operating procedure (SOP) terkait PBB-P2 sebagai bahan acuan pemerintah daerah dalam menyusun SOP;

3. Struktur, tugas, dan fungsi organisasi Direktorat Jenderal Pajak terkait pemungutan PBB-P2 sebagai bahan acuan pemerintah daerah untuk merumuskan struktur organisasi dan tata kerja pemungutan PBB-P2;

4. Data piutang PBB-P2 beserta data pendukungnya;

5. Surat Keputusan Menteri Keuangan mengenai penetapan Nilai Jual Objek Pajak Tidak Kena Pajak (NJOPTKP) yang berlaku dalam kurun waktu 10 (sepuluh) tahun sebelum Tahun Pengalihan;

6. Salinan Peta Desa/Kelurahan, Peta Blok, dan Peta Zona Nilai Tanah dalam bentuk softcopy;

7. Hasil penggandaan basis data PBB-P2 sebelum Tahun Pengalihan; dan

8. Hasil penggandaan sistem aplikasi terkait PBB-P2 beserta source code-nya;

Berdasarkan Peraturan Bersama Menteri Keuangan dan Menteri Dalam

Negeri Nomor 213/PMK.07/2010 Nomor 58 Tahun 2010 Tentang Tahapan

Persiapan Pengalihan Pajak Bumi dan Bangunan Perdesaan dan Perkotaan Sebagai Pajak Daerah pasal (7), terdapat beberapa elemen yang harus dipenuhi oleh daerah untuk menerima pengalihan PBB-P2, yaitu:

1. Sarana dan prasarana;

2. Struktur organisasi dan tata kerja;

3. Sumber daya manusia;

4. Peraturan Daerah, Peraturan Kepala Daerah, dan SOP;

5. Kerjasama dengan pihak terkait, antara lain, Kantor Pelayanan Pajak, Perbankan, Kantor Pertanahan, dan Notaris/Pejabat Pembuat Akta Tanah, Kantor Lelang;dan 
6. Pembukaan rekening penerimaan PBB-P2 pada bank yang sehat.

\section{PENGEMBANGAN HIPOTESIS}

Penelitian yang dilakukan oleh Ruswandi (2009) mengatakan bahwa peningkatan penerimaan pajak daerah disebabkan bertambahnya objek pajak di kabupaten Sumedang yaitu Pajak Hotel, Pajak Restoran, Pajak Bahan Galian Gol. C dan Pajak Pemanfaatan Air Bawah Tanah dan Air Permukaan. Hal ini berarti, jika didalam suatu daerah terjadi penambahan objek pajak maka dapat meningkatkan penerimaan pajak daerah yang akhirnya akan berpengaruh terhadap Pendapatan Asli Daerah (PAD). Temuan Suwarno dan Suhartiningsih (2008) menyatakan bahwa besarnya pengenaan pajak daerah akan meningkat sejalan kenaikan penerimaan Pendapatan Asli Daerah. Namun, hal ini bisa tidak berpengaruh karena adanya faktor fluktuasi serta melihat besarnya kontribusi masing-masing pajak daerah di Kabupaten Sukoharjo.

Penelitian Tasniwati (2010) mengemukakan bahwa pendaerahan PBB-P2 akan memperkuat struktur keuangan daeah sehingga potensi masing-masing kab./kota akan dapat digali sehingga memaksimalkan realisasi PBB terhutang sebesar 100\%. Penelitian Baggijo (2011) mengemukakan posisi PDRD

sangat strategis bagi penyelenggaraan Pemda khususnya indikatior keberhasilan otonomi daerah sebagai aspek kemampuan daerah untuk membiayai pelaksanaan pengeluaran daerah.

Berdasarkan uraian diatas hipotesis yang diajukan adalah:

$\mathrm{H}_{\mathrm{a}}=$ Terdapat perbedaan jumlah penerimaan PBB-P2 sebelum dan sesudah penerapan PBB-P2 sebagai pajak daerah.

\section{METODE PENELITIAN}

\section{Jenis Penelitian}

Penelitian ini menggunakan metode kuantitatif dengan pendekatan deskriptif. Objek penelitian ini adalah melihat persepsi aparat pemerintah daerah terhadap pelaksanaan PBB-P2 serta realisasi penerimaan PBB-P2 sebelum dan sesudah sebagai pajak daerah.

\section{Populasi dan Sampel}

Populasi penelitian ini adalah aparat DPPKA (penagihan dan pelayanan) dan UPTD kabupaten Sidoarjo berjumlah 43 responden dan penerimaan PBB-P2 tiap kecamatan $(n=18)$ tahun 2011-2012. Sampel penelitian ini adalah aparat DPPKA (penagihan dan pelayanan) dan UPTD kabupaten Sidoarjo berjumlah 43 responden. Kedua bagian tersebut terlibat secara langsung pelaksanaan PBB-P2 sebagai pajak daerah. Perlu diketahui, UPTD Kabupaten Sidoarjo baru dibentuk bulan Agustus 2012 sebagai bagian DPKKA di wilayah yang telah ditentukan. Berikut adalah pembagian wilayah UPTD Kabupaten Sidoarjo: 
Tabel 2. Pembagian Wilayah Uptd Kabupaten Sidoarjo

\section{Unit Pelayanan Teknis Daerah Kabupaten Sidoarjo}

\begin{tabular}{llll}
\multicolumn{1}{c}{ UPTD Sidoarjo } & \multicolumn{1}{c}{ UPTD Tulangan } & \multicolumn{1}{c}{ UPTD Krian } & \multicolumn{1}{c}{ UPTD Taman } \\
\hline Kec. Sidoarjo & Kec. Tulangan & Kec. Krian & Kec. Taman \\
Kec. Candi & Kec. Tanggulangin & Kec. Wonoayu & Kec. Waru \\
Kec. Buduran & Kec. Jabon & Kec. Balongbendo & Kec. Sukodono \\
Kec. Gedangan & Kec. Porong & Kec. Tarik & Kec. Sedati \\
& Kec. Krembung & Kec. Prambon & \\
\hline
\end{tabular}

Sumber: DPPKA Kabupaten Sidoarjo

Penelitian ini, mengambil teknik pengambilan sampel nonprobability sampling. Teknik ini digunakan untuk seluruh populasi aparat DPPKA (penagihan \& pelayanan) dan UPTD Kabupaten Sidoarjo dan realisasi penerimaan PBB-P2 tahun 2011-2012 (penelitian populasi).

\section{Operasionalisasi Variabel}

Rumusan masalah pertama penelitian menggunakan kuisioner sehingga pengukurannya menggunakan skala ordinal dengan jenis skala likert. Terdapat enam variabel yang akan mengukur persepsi aparat Pemda terhadap penerapan PBB-P2 dan dilakukan pengujian statistik yaitu:

1. Sarana dan prasarana (X1);

2. Struktur organisasi dan tata kerja (X2);

3. Sumber daya manusia (X3);

4. Perda, perkada dan SOP (X4);

5. Kerjasama dengan pihak terkait (X5); dan

6. Pembukaan rekening pada bank yang sehat.

Penelitian ini menggunakan rentangan skor: Sangat tidak baik (STB) skor 1, Tidak baik (TB) skor 2, Cukup baik (CB) skor 3, Baik (B) skor 4 dan Sangat baik (SB) skor 5.

Rumusan masalah kedua menggunakan data sekunder berupa penerimaan PBB-P2 tahun 2011-2012 dengan identifikasi variabel adalah sebagai berikut:

$\mathrm{H}_{\mathrm{a}}=$ Terdapat perbedaan jumlah penerimaan PBB-P2 sebelum dan sesudah penerapan PBB-P2 sebagai pajak daerah.

\section{Teknik Analisis Data}

Teknik analisis data penelitian ini menggunakan statistik inferensial yang memanfaatkan software SPSS 20.0 for windows. Rumusan masalah pertama menggunakan kuisioner kepada aparat DPPKA (penagihan dan pelayanan) dan UPTD Kabupaten Sidoarjo. Pengujian kualitas datanya menggunakan uji validitas dan reliabilitas dengan penguatan hasil wawancara. Sedangkan rumusan masalah kedua dijawab menggunakan uji normalitas untuk memenuhi distribusi kenormalan data serta Uji T Sampel Berpasangan (Paired Sample t-test). 


\section{HASIL DAN PEMBAHASAN}

\section{Deskripsi Jawaban Responden Terhadap Hasil Penelitian}

Kuisioner yang telah disebarkan kemudian dilakukan analisa dengan memberikan prosentase untuk setiap indikator dalam variabel penelitian tersebut. Berikut adalah hasil dekripsi jawaban responden:

\section{Sarana dan Prasarana (X1)}

\section{a. Perangkat Keras (hardware)}

Indikator ini bertujuan untuk mengukur apakah perangkat keras dapat membantu kinerja aparatur dalam melaksanakan penerapan PBB-P2 sebagai pajak daerah sehingga memaksimalkan pelayanan kepada masyarakat. Berikut adalah tabel tanggapan responden tentang indikator ini:

Tabel 3. Jawaban Responden Tentang Perangkat Keras

\begin{tabular}{ccccc}
\hline No & Jawaban responden & Bobot & Frekuensi Responden & Prosentase \\
\hline 1 & Sangat tidak baik & 1 & 0 & 0 \\
2 & Tidak baik & 2 & 0 & 0 \\
3 & Cukup baik & 3 & 7 & $20,6 \%$ \\
4 & Baik & 4 & 17 & $50,0 \%$ \\
5 & Sangat baik & 5 & 10 & $29,4 \%$ \\
& Total & & $\mathbf{3 4}$ & $\mathbf{1 0 0 \%}$ \\
\hline
\end{tabular}

Sumber: Data Diolah melalui SPSS 20, 2013

Berdasarkan tabel 4 diketahui tujuh responden memberikan jawaban cukup baik $(20,6 \%)$ sedangkan 17 responden memberikan jawaban baik (50\%) sisanya 10 responden memberikan jawaban sangat baik (29,4\%). Hasil tersebut mengindikasikan sebagian besar aparatur menilai bahwa perangkat keras yang digunakan dalam pelaksanaan PBB-P2 dalam kondisi baik dan digunakan sesuai fungsinya. Hal ini menunjukkan perangkat keras sangat membantu pekerjaan pemerintah daerah dalam penerapan PBB-P2 sebagai pajak daerah.

\section{b. Perangkat Lunak (software)}

Indikator ini bertujuan untuk mengukur apakah perangkat lunak dapat membantu kinerja aparatur dalam melaksanakan penerapan PBB-P2 sebagai pajak daerah sehingga memaksimalkan pelayanan kepada masyarakat. Berikut adalah tabel tanggapan responden tentang indikator ini:

Tabel 4. Jawaban Responden Tentang Perangkat Lunak

\begin{tabular}{ccccc}
\hline No & Jawaban responden & Bobot & $\begin{array}{c}\text { Frekuensi } \\
\text { Responden }\end{array}$ & Prosentase \\
\hline 1 & Sangat tidak baik & 1 & 0 & 0 \\
2 & Tidak baik & 2 & 0 & 0 \\
3 & Cukup baik & 3 & 2 & $5,9 \%$ \\
4 & Baik & 4 & 25 & $73,5 \%$ \\
5 & Sangat baik & 5 & 7 & $20,6 \%$ \\
& Total & & $\mathbf{3 4}$ & $\mathbf{1 0 0 \%}$ \\
\hline
\end{tabular}

Sumber: Data Diolah melalui SPSS 20, 2013 
Berdasarkan tabel 5 diketahui dua responden memberikan jawaban cukup baik dengan prosentase 5,9\% sedangkan 25 responden memberikan jawaban baik dengan prosentase $73,5 \%$ sisanya 7 responden memberikan jawaban sangat baik dengan prosentase $20,6 \%$. Hasil tersebut mengindikasikan lebih dari separuh responden menilai baik adanya perangkat lunak sangat membantu aparatur dalam melaksanakan PBB-P2 sebagai pajak daerah. Perangkat lunak begitu penting karena berhubungan dengan data-data wajib pajak beserta data pendukung lainnya.

\section{c. Data}

Indikator ini bertujuan untuk mengukur apakah kepemilikan data-data yang berhubungan dengan PBB-P2 telah lengkap untuk menunjang pelaksanaan PBB-P2 sebagai pajak daerah. Berikut adalah tabel tanggapan responden tentang indikator ini:

Tabel 5. Jawaban Responden Tentang Data

\begin{tabular}{ccccc}
\hline No & Jawaban responden & Bobot & $\begin{array}{c}\text { Frekuensi } \\
\text { Responden }\end{array}$ & Prosentase \\
\hline 1 & Sangat tidak baik & 1 & 0 & 0 \\
2 & Tidak baik & 2 & 0 & 0 \\
3 & Cukup baik & 3 & 17 & $50,0 \%$ \\
4 & Baik & 4 & 14 & $41,2 \%$ \\
5 & Sangat baik & 5 & 3 & $8,8 \%$ \\
& Total & & $\mathbf{3 4}$ & $\mathbf{1 0 0 \%}$ \\
\hline
\end{tabular}

Sumber: Data Diolah melalui SPSS 20, 2013

Berdasarkan tabel 6 diketahui 17 responden memberikan jawaban cukup baik dengan prosentase $50 \%$ sedangkan 14 responden memberikan jawaban baik dengan prosentase $41,2 \%$ sisanya 3 responden memberikan jawaban sangat baik dengan prosentase $8,8 \%$. Hasil tersebut mengindikasikan sebagian besar responden memberikan jawaban cukup baik untuk kepemilikan database PBB-P2 guna menunjang penerapan PBB-P2 sebagai pajak daerah. Hal ini berarti kepemilikan database harus lebih diperbaharui.

\section{d. Formulir-formulir}

Indikator ini bertujuan untuk mengukur apakah kepemilikan formulirformulir yang berhubungan dengan PBB-P2 telah lengkap untuk menunjang pelaksanaan PBB-P2 sebagai pajak daerah. Berikut adalah tabel tanggapan responden tentang indikator ini:

Tabel 6. Jawaban Responden Tentang Formulir-Formulir

\begin{tabular}{ccccc}
\hline No & Jawaban responden & Bobot & $\begin{array}{c}\text { Frekuensi } \\
\text { Responden }\end{array}$ & Prosentase \\
\hline 1 & Sangat tidak baik & 1 & 0 & 0 \\
2 & Tidak baik & 2 & 0 & 0 \\
3 & Cukup baik & 3 & 8 & $23,5 \%$ \\
4 & Baik & 4 & 14 & $41,2 \%$ \\
5 & Sangat baik & 5 & 12 & $35,3 \%$ \\
& Total & & $\mathbf{3 4}$ & $\mathbf{1 0 0 \%}$ \\
\hline
\end{tabular}

Sumber: Data Diolah melalui SPSS 20, 2013 
Berdasarkan tabel 7 diketahui delapan responden memberikan jawaban cukup baik $(23,5 \%)$ sedangkan 14 responden memberikan jawaban baik $(41,2 \%)$ sisanya 12 responden memberikan jawaban sangat baik (35,3\%). Hasil tersebut mengindikasikan sebagian besar responden memberikan jawaban baik untuk kepemilikan formulir yang digunakan berbagai keperluan yang berhubungan dengan PBB-P2 seperti pendaftaran objek baru PBB-P2. Hal ini menunjukkan penyediaan formulir adalah lengkap dan sesuai beserta lampiran-lampirannya.

\section{e. Pelayanan}

Indikator ini bertujuan untuk mengukur apakah pelayanan PBB-P2 adalah sesuai dengan tugas dan fungsi pemerintah daerah sehingga pelaksanaan PBB-P2 sebagai pajak daerah akan lebih maksimal. Berikut adalah tabel tanggapan responden tentang indikator ini:

Tabel 7. Jawaban Responden Tentang Pelayanan

\begin{tabular}{ccccc}
\hline No & Jawaban responden & Bobot & $\begin{array}{c}\text { Frekuensi } \\
\text { Responden }\end{array}$ & Prosentase \\
\hline 1 & Sangat tidak baik & 1 & 0 & 0 \\
2 & Tidak baik & 2 & 0 & 0 \\
3 & Cukup baik & 3 & 7 & $20,6 \%$ \\
4 & Baik & 4 & 22 & $64,7 \%$ \\
5 & Sangat baik & 5 & 5 & $14,7 \%$ \\
& Total & & $\mathbf{3 4}$ & $\mathbf{1 0 0 \%}$ \\
\hline
\end{tabular}

Sumber: Data Diolah melalui SPSS 20, 2013

Berdasarkan tabel 8 diketahui tujuh responden memberikan jawaban cukup baik dengan prosentase $20,6 \%$ sedangkan 22 responden memberikan jawaban baik dengan prosentase $64,7 \%$ sisanya lima responden memberikan jawaban sangat baik dengan prosentase 14,7\%. Hasil tersebut mengindikasikan sebagian besar responden memberikan jawaban baik untuk pelayanan keluhan dan pembayaran PBB-P2 yang terjadi setiap harinya pada waktu jam kerja. Hal ini menunjukkan penerapan PBB-P2 telah berjalan baik. Dari kelima indikator sarana dan prasarana, rata-rata responden memberikan jawaban baik untuk penyediaan sarana dan prasarana sehingga membantu kinerja aparatur dalam penerapan PBB-P2 sebagai pajak daerah.

\section{Struktur Organisasi dan Tata Kerja (X2)}

Indikator ini bertujuan untuk mengukur apakah pelaksanaan PBB-P2 sebagai pajak daerah telah sesuai dengan SOTK yang telah ada. Berikut adalah tabel tanggapan responden tentang indikator ini: 
Tabel 8. Jawaban Responden Tentang Struktur Organisasi Dan Tata Kerja

\begin{tabular}{ccccc}
\hline No & Jawaban responden & Bobot & $\begin{array}{c}\text { Frekuensi } \\
\text { Responden }\end{array}$ & Prosentase \\
\hline 1 & Sangat tidak baik & 1 & 0 & 0 \\
2 & Tidak baik & 2 & 0 & 0 \\
3 & Cukup baik & 3 & 8 & $23,5 \%$ \\
4 & Baik & 4 & 22 & $64,7 \%$ \\
5 & Sangat baik & 5 & 4 & $11,8 \%$ \\
& Total & & $\mathbf{3 4}$ & $\mathbf{1 0 0 \%}$ \\
\hline
\end{tabular}

Sumber: Data Diolah melalui SPSS 20, 2013

Berdasarkan tabel 9 diketahui delapan responden memberikan jawaban cukup baik $(23,5 \%)$ sedangkan 22 responden memberikan jawaban baik $(64,7 \%)$ sisanya empat responden memberikan jawaban sangat baik $(11,8 \%)$. Hasil tersebut mengindikasikan sebagian besar responden memberikan jawaban baik untuk adanya struktur organisasi dan tata kerja dalam melaksanakan penerapan PBB-P2 sebagai pajak daerah. SOTK sangat dibutuhkan karena untuk mengatur pembagian kerja masing-masing aparatur sesuai dengan fungsinya.

\section{Sumber Daya Manusia (X3)}

Indikator ini bertujuan untuk mengukur apakah pelaksanaan PBB-P2 sebagai pajak daerah telah ditangani oleh aparatur yang berkompeten dan telah mendapatkan bimbingan serta pelatihan. Berikut adalah tabel tanggapan responden tentang indikator :

Tabel 9. Jawaban Responden Tentang Sumber Daya Manusia

\begin{tabular}{ccccc}
\hline No & Jawaban responden & Bobot & $\begin{array}{c}\text { Frekuensi } \\
\text { Responden }\end{array}$ & Prosentase \\
\hline 1 & Sangat tidak baik & 1 & 0 & 0 \\
2 & Tidak baik & 2 & 0 & 0 \\
3 & Cukup baik & 3 & 8 & $23,5 \%$ \\
4 & Baik & 4 & 21 & $61,8 \%$ \\
5 & Sangat baik & 5 & 5 & $14,7 \%$ \\
& Total & & $\mathbf{3 4}$ & $\mathbf{1 0 0 \%}$ \\
\hline
\end{tabular}

Sumber: Data Diolah melalui SPSS 20, 2013

Berdasarkan tabel 10 diketahui delapan responden memberikan jawaban cukup baik dengan prosentase $23,5 \%$ sedangkan 21 responden memberikan jawaban baik dengan prosentase $61,8 \%$ sisanya lima responden memberikan jawaban sangat baik dengan prosentase $14,7 \%$. Hasil tersebut mengindikasikan sebagian besar responden memberikan jawaban baik untuk sumber daya manusia yang menangani pelaksanaan PBB-P2 sebagai pajak daerah. Sumber daya manusia tersebut telah berkompeten dibidangnya karena telah mengikuti pendidikan dan pelatihan tekni selama empat bulan sehingga dapat meningkatkan kinerjanya.

\section{Perda, Perkada, dan SOP (X4)}

Indikator ini bertujuan untuk mengukur apakah pelaksanaan PBB-P2 sebagai pajak daerah telah sesuai dengan undang-undang dan peraturan yang telah 
dibuat oleh pemerintah daerah. Berikut adalah tabel tanggapan responden tentang indikator ini:

Tabel 10. Jawaban Responden Tentang Perda, Perkada dan SOP

\begin{tabular}{lcccc}
\hline No & Jawaban responden & Bobot & $\begin{array}{c}\text { Frekuensi } \\
\text { Responden }\end{array}$ & Prosentase \\
\hline 1 & Sangat tidak baik & 1 & 0 & 0 \\
2 & Tidak baik & 2 & 0 & 0 \\
3 & Cukup baik & 3 & 4 & $11,8 \%$ \\
4 & Baik & 4 & 17 & $50,0 \%$ \\
5 & Sangat baik & 5 & 13 & $38,2 \%$ \\
& Total & & $\mathbf{3 4}$ & $\mathbf{1 0 0 \%}$ \\
\hline
\end{tabular}

Sumber: Data Diolah melalui SPSS 20, 2013

Berdasarkan tabel 11 diketahui empat responden memberikan jawaban cukup baik dengan prosentase $11,8 \%$ sedangkan 17 responden memberikan jawaban baik dengan prosentase $50 \%$ sisanya 13 responden memberikan jawaban sangat baik dengan prosentase $38,2 \%$. Hasil tersebut mengindikasikan sebagian besar responden memberikan jawaban baik untuk adanya peraturan daerah, peraturan kepala daerah dan SOP yang telah dibuat oleh pemerintah daerah. Adanya undang-undang dan peraturan tersebut digunakan sebagai acuan dan pedoman untuk pemerintah daerah khususnya DPPKA untuk melaksanakan penerapan PBB-P2 sebagai pajak daerah.

\section{Kerjasama Dengan Pihak Terkait (X5)}

Indikator ini bertujuan untuk mengukur apakah pelaksanaan PBB-P2 sebagai pajak daerah telah terjalin hubungan kerjasama dengan pihak-pihak terkait seperti KPP, perbankan, kantor pertanahan, notaris/PPAT dan kantor Lelang. Berikut adalah tabel tanggapan responden tentang indikator ini:

Tabel 11. Jawaban responden tentang kerjasama dengan pihak terkait

\begin{tabular}{ccccc}
\hline No & Jawaban responden & Bobot & $\begin{array}{c}\text { Frekuensi } \\
\text { Responden }\end{array}$ & Prosentase \\
\hline 1 & Sangat tidak baik & 1 & 0 & 0 \\
2 & Tidak baik & 2 & 0 & 0 \\
3 & Cukup baik & 3 & 11 & $32,4 \%$ \\
4 & Baik & 4 & 18 & $52,9 \%$ \\
5 & Sangat baik & 5 & 5 & $14,7 \%$ \\
& Total & & $\mathbf{3 4}$ & $\mathbf{1 0 0 \%}$ \\
\hline
\end{tabular}

Sumber: Data Diolah melalui SPSS 20, 2013

Berdasarkan tabel 12 diketahui sebelas responden memberikan jawaban cukup baik dengan prosentase 32,4\% sedangkan 18 responden memberikan jawaban baik dengan prosentase $52,9 \%$ sisanya lima responden memberikan jawaban sangat baik dengan prosentase 14,7\%. Hasil tersebut mengindikasikan sebagian besar responden memberikan jawaban baik untuk adanya kerjasama yang telah dilakukan oleh DPPKA dengan beberapa pihak seperti KPP, perbankan, kantor 
pertanahan, notaris/PPAT dan kantor pertanahan. Kerjasama tersebut sering dilakukan karena untuk segala pengurusan surat-surat akan selalu berhubungan dengan pihak-pihak terkait. Hal ini menunjukkan adanya kerjasama yang baik antara DPPKA dengan pihak ketiga sebagai partner.

\section{Pembukaan Rekening Pada Bank Yang Sehat (X6)}

Indikator ini bertujuan untuk mengukur apakah perbankan yang ditunjuk oleh pemerintah daerah adalah bank yang sehat untuk menunjang pelaksanaan PBB-P2 sebagai pajak daerah. Berikut adalah tabel tanggapan responden tentang indikator ini:

Tabel 12. Jawaban Responden Tentang Pembukaan Rekening Pada Bank Yang Sehat

\begin{tabular}{ccccc}
\hline No & Jawaban responden & Bobot & $\begin{array}{c}\text { Frekuensi } \\
\text { Responden }\end{array}$ & Prosentase \\
\hline 1 & Sangat tidak baik & 1 & 0 & 0 \\
2 & Tidak baik & 2 & 0 & 0 \\
3 & Cukup baik & 3 & 7 & $20,6 \%$ \\
4 & Baik & 4 & 21 & $61,8 \%$ \\
5 & Sangat baik & 5 & 6 & $17,6 \%$ \\
& Total & & 34 & $100 \%$ \\
\hline
\end{tabular}

Sumber: Data Diolah melalui SPSS 20, 2013

Berdasarkan tabel 13 diketahui tujuh responden memberikan jawaban cukup baik dengan prosentase 20,6\% sedangkan 21 responden memberikan jawaban baik dengan prosentase $61,8 \%$ sisanya enam responden memberikan jawaban sangat baik dengan prosentase 17,6\%. Hasil tersebut mengindikasikan sebagian besar responden memberikan jawaban baik untuk pembukaan rekening pada bank yang sehat. Pembukaan rekening pada bank yang sehat akan menjadi penting karena seluruh transaksi pembayaran PBB-P2 akan melalui perbankan yang bersangkutan yaitu Bank Jatim.

\section{Deskripsi Penerimaan PBB-P2}

Pajak daerah yang dikelola oleh kabupaten Sidoarjo terdiri dari sepuluh macam pajak daerah, salah satunya PBB-P2 yang merupakan pajak daerah baru kabupaten Sidoarjo tahun 2012. Penerapan PBB-P2 sebagai pajak daerah maka penerimaan daerah kabupaten Sidoarjo bertambah. Penerimaan PBB-P2 kabupaten Sidoarjo tahun 2011-2012 disajikan gambar berikut:

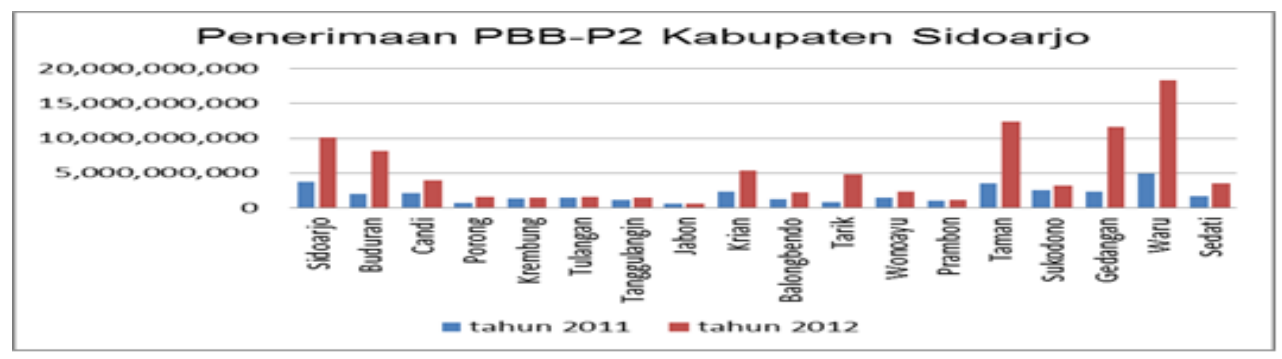

Gambar 2: Penerimaan PBB-P2 kabupaten Sidoarjo 
Pada gambar 2 penerimaan PBB-P2 tahun 2011 adalah dana bagi hasil yang bagikan oleh pemerintah pusat kepada kabupaten dengan prosentase $64,8 \%$. Jumlah penerimaan tersebut adalah penerimaan yang masuk ke dalam kas daerah sehingga detail pembagian penerimaannya tidak diketahui. Sedangkan penerimaan PBB-P2 tahun 2012 adalah hasil murni 100\% ketika PBB-P2 telah menjadi pajak daerah sehingga seluruh kecamatan di kabupaten Sidoarjo mengalami kenaikan penerimaan yang cukup tinggi. Perbedaan tersebut terlihat dalam gambar di atas diman terjadi kenaikan penerimaan di seluruh kecamatan dengan kenaikan yang cukup tinggi dan signifikan dibandingkan ketika PBB-P2 masih menjadi pajak pusat.

Hal ini juga terjadi karena adanya persepsi aparatur pemerintah daerah adalah baik terhadap penerapan PBB-P2 sebagai pajak daerah. Pengukuran persepsi ini dilakukan menggunakan kuisioner yang telah ditabulasi dan dianalisa. Ketika persepsi aparatur adalah baik maka penerimaan PBB-P2 akan meningkat karena aparatur akan lebih giat dalam menggalakkan sosialisasi pendaerahan PBB-P2 serta aktif melakukan operasi sisir di tiap-tiap kecamatan di mana sebelum terjadi pendaerahan, pembayaran PBB-P2 dilakukan oleh penarikan kepala desa atau lurah masing-masing kecamatan.

\section{Pengujian Hipotesis}

Pengujian hipotesis menggunakan uji $\mathrm{t}$ data sampel berpasangan (Paired Sample t-Test). Uji t untuk sampel berpasangan digunakan untuk menguji perbedaan rata-rata antara dua sampel berpasangan. Berikut adalah hasil pengujian hipotesis data penerimaan PBB-P2 sebelum dan sesudah penerapan tahun 2011-2012 sebagai berikut:

Tabel 13. Paired Sample t-Test Penerimaan PBB-P2 Tahun 2011-2012

Paired Samples Statistics

\begin{tabular}{lllllr}
\hline & & \multicolumn{1}{c}{ Mean } & N & \multicolumn{1}{l}{ Std. Deviation } & \multicolumn{1}{c}{ Std. Error Mean } \\
\hline \multirow{2}{*}{ Pair 1 } & Sebelum & 1945315015.44 & 18 & 1161623025.257 & 273797172.781 \\
& Sesudah & 5205714619.72 & 18 & 4921405560.033 & 1159986414.823 \\
\hline
\end{tabular}

Paired Samples Correlations

\begin{tabular}{|c|c|c|c|c|}
\hline & & $\mathrm{N}$ & Correlation & Sig. \\
\hline Pair 1 & sebelum \& sesudah & 18 & .884 & .000 \\
\hline
\end{tabular}

Paired Samples Test

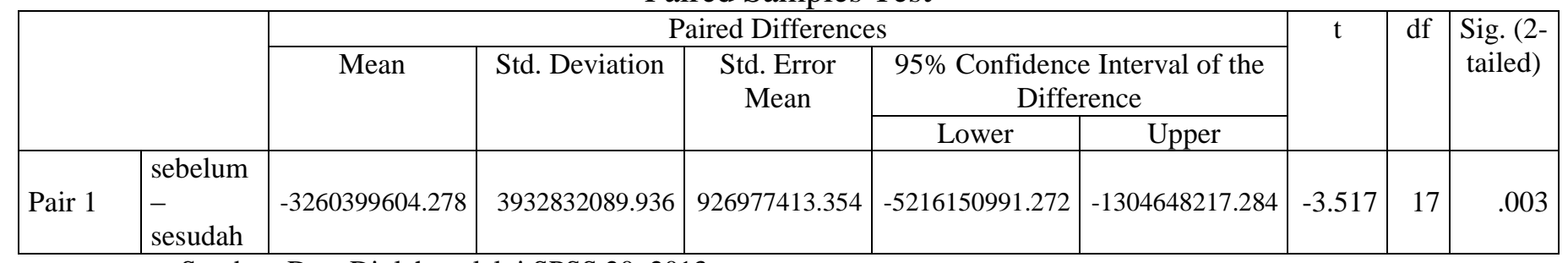

Sumber: Data Diolah melalui SPSS 20, 2013 
Berdasarkan tabel 14 diketahui nilai - $\mathrm{t}_{\text {hitung }}<-\mathrm{t}$ tabel yaitu $-3,517<-2,110$ maka $\mathrm{H}_{\mathrm{a}}$ diterima. Berdasarkan signifikansinya adalah $<0,05(0,003<0,05)$ maka $\mathrm{H}_{\mathrm{a}}$ diterima. Kesimpulannya terjadi perbedaan kenaikan penerimaan PBB-P2 sebelum dengan sesudah penerapan PBB-P2 sebagai pajak daerah. Hal ini menunjukkan penerapan PBB-P2 terbukti meningkatkan penerimaan PBB-P2 serta berpengaruh terhadap PAD kabupaten Sidoarjo yang meningkat.

Berdasarkan tabel-tabel yang telah disajikan dalam subbab sebelumnya terlihat bahwa penerimaan PBB-P2 mengalami peningkatan ketika PBB-P2 telah menjadi objek pajak daerah. Peningkatan penerimaan tersebut dikarenakan adanya persepsi aparatur (DPPKA dan UPTD) terhadap penerapan PBB-P2 sebagai pajak daerah adalah baik berdasarkan prosentase jawaban yang telah dilakukan tabulasi dan dianalisa dalam subbab sebelumnya. Persepsi aparatur dikatakan baik karena hampir dari seluruh responden mengukur masing-masing variabel penelitian dengan jawaban baik dengan prosentase lebih dari 50\%. Hal ini membuktikan ketika persepsi aparatur baik maka akan meningkatkan penerimaan PBB-P2 setelah adanya pendaerahan. Dengan persepsi baik yang artinya seluruh aparatur memahami dan mengetahui benar bagaiman penerapan PBB-P2 sebagai pajak daerah sehingga kegiatan sosialisasi akan terus digalakkan. Selain itu, aparatur akan lebih giat melakukan operasi sisir untuk menjemput bola yang artinya turun langsung ke desa-desa untuk mendatangi masyarakat yang akan membayar PBBP2. Dengan begitu aparatur akan lebih dekat kepada masyarakat dan tidak akan ada lagi pungutan liar yang terjadi seperti masih menjadi pajak pusat.

\section{SIMPULAN DAN SARAN}

Hasil penelitian yang memberikan bukti secara empiris menyimpulkan bahwa persepsi aparatur DPPKA dan UPTD kabupaten Sidoarjo terhadap enam instrumen pengalihan PBB-P2 sebagai pajak daerah dengan jawaban responden adalah baik berdasarkan prosentase yang ada. Hal tersebut sesuai dengan Perda Kabupaten Sidoarjo Nomor 11 Tahun 2011 menurut Peraturan Bersama Menteri Keuangan dan Menteri Dalam Negeri Nomor 213/PMK.07/2010 Nomor 58 Tahun 2010 .

Hasil uji t sampel berpasangan untuk penerimaan PBB-P2 menunjukkan terjadi perbedaan sebelum dan sesudah penerapan sebagai pajak daerah. Ketika persepsi aparatur pemerintah daerah menilai bahwa penerapan PBB-P2 sebagai pajak daerah adalah baik maka hal tersebut akan berdampak terhadap kenaikan penerimaan PBB-P2 setelah adanya pendaerahan. Hal ini terjadi karena aparatur akan lebih giat melakukan sosialisasi pendaerahan PBB-P2 kepada masyarakat dan aktif melakukan operasi sisir untuk langsung melayani pembayaran PBB-P2 di masing-masing kecamatan bahkan desa sehingga tidak lagi terjadi pungutan ketika masih menjadi pajak pusat.

Saran untuk penelitian selanjutnya adalah penggunaan metodologi mix method yaitu memadukan penelitian kuantitatif dengan penelitian kualitatif dan lebih baik jika objek penelitian dilakukan di kabupaten atau kota yang telah menerapkan PBB-P2 sebagai pajak daerah serta bagi pemerintah daerah perlu 
kiranya aktif melakukan survei dan operasi sisir untuk bisa menetapkan objekobjek baru PBB-P2 sehingga akan lebih meningkatkan jumlah Wajib PBB-P2. 


\section{DAFTAR PUSTAKA}

Bagijo, Himawan Estu, 2011. Pajak dan Retribusi Daerah Sebagai Sumber Pendapatan Daerah (Studi Kasus Di Kabupaten/Kota Dan Pemerintahan Jawa Timur). Jurnal Perspektif. Vol. 16, No.1:12-30.

Faisol, Imam Agus, 2012. Analisis Kesiapan Daerah Menerima Wewenang PBB Menjadi Pajak Daerah. Skripsi. Madura: Fakultas Ekonomi Universitas Trunojoyo.

Ghozali, H.Imam. 2006. Aplikasi Analisis Multivariate Dengan Program SPSS. Semarang: Penerbit Universitas Diponegoro

Republik Indonesia. Undang-Undang Nomor 12 Tahun 1985 Tentang Pajak Bumi dan Bangunan.

Republik Indonesia. Undang-Undang Nomor 28 Tahun 2009 Tentang Pajak Daerah dan Retribusi Daerah.

Republik Indonesia. Peraturan Bersama Menteri Keuangan dan Menteri Dalam Negeri Nomor 213/PMK.07/2010 Tentang Tahapan Persiapan Pengalihan Pajak Bumi dan Bangunan Perdesaan dan Perkotaan Sebagai Pajak Daerah.

Republik Indonesia. Peraturan Daerah Kabupaten Sidoarjo Nomor 11 Tahun 2011 Tentang Pajak Bumi dan Bangunan Perdesaan dan Perkotaan.

Republik Indonesia. Peraturan Bupati Sidoarjo Nomor 55 Tahun 2011 Tentang Tata Cara Pemungutan Pajak Bumi dan Bangunan Perdesaan dan Perkotaan.

Ruswandi, Rina Rahmawati, 2009. Analisis Pengaruh Pajak Daerah Terhadap Pendapatan Asli Daerah Di Kabupaten Sumedang. Skripsi. Bogor: Fakultas Ekonomi dan Manajemen Institut Pertanian Bogor.

Sari, Yulia Anggara, 2010. Analisis Efektifitas dan Kontribusi Penerimaan Pajak Bumi dan Bangunan Terhadap Pendapatan Daerah di Kota Bandung. Jurnal Wacana Kerja, Vol. 13, No.2:173-185.

Sugiyono. 2012. Metodologi Penelitian Bisnis. Bandung: Penerbit ALFABETA.

Suwarno, Agus Endro dan Suhartiningsih, 2008. Efektifitas Evaluasi Potensi Pajak Daerah Sebagai Sumber Pendapatan Asli Daerah. Jurnal Akuntansi dan Keuangan. Vol. 7, No.2:162-173.

Tasniwati, 2010. Tinjauan Peranan Pajak Bumi dan Bangunan Sebagai Pajak Daerah Di Kabupaten Sidoarjo. Tesis. Depok: Program Magister Perencanaan dan Kebijakan Publik Universitas Indonesia. 